\title{
Gathering up the Fragments after Boko Haram
}

\section{Helping Baptist Churches in Northeastern Nigeria Recover, Conserve, and Digitize their History}

By Anthonia O. Ahimah, Ibrahim Danin Library, Baptist Theological Seminary, Kaduna, Nigeria; D’Anna Shotts, Ibrahim Danin Library Baptist Theological Seminary, Kaduna, Nigeria

ABSTRACT Almost everyone has heard of the deadly terror group Boko Haram, which began to gain world attention in 2009. Their impact on northeastern Nigeria has been devastating: lives lost and disrupted, properties destroyed, culture and history eradicated by violence. Though they no longer hold territory, in 2014-15 Boko Haram controlled an area the size of Belgium, and also carried out multiple violent attacks in surrounding areas. The Northeastern Nigeria Baptist Digital History Project was begun to help affected Baptist churches in three northeastern states which suffered invasion, many of them with devastated and scattered congregations and damaged or destroyed buildings, recover the dignity of their history through researching, locating, digitizing, and indexing historical documents related to their founding and growth.

Original impetus for the project, headquartered in the Ibrahim Danin Library of Baptist Theological Seminary, Kaduna (located outside the Boko Haram sphere of influence), was the discovery of a trove of fortyyear-old, handwritten working files created by missionaries present at the founding of many of the earliest Baptist churches in the area. Other primary materials already held by the Library contain clues to interpreting these records, and are also being digitized for access by scholars and researchers. 


\section{INTRODUCTION}

Nigeria, sometimes known as "the Giant of Africa," has around 200 million people. Approximately half are Christian and half are Muslim, though there is also a smattering of purely traditional worshippers as well. (African Traditional Religion underlies much of Islam and Christianity in the country, as well.) Islam came down through the Sahara Desert into Northern Nigeria with Arab traders on camel caravans from the twelfth century. Christianity arrived with Catholic priests accompanying Portuguese explorers in the Bight of Benin off the southern coast in the fifteenth century, but didn't really take root until the "Great Advance" of European and American missions in the nineteenth century (which was centered in southwest Nigeria). So, the interaction between religions is nothing new in the country, but the intensity and potential for violence has greatly increased as the two "missionary" faiths continue to grow rapidly amid difficult social and economic circumstances.

With a long history of religious activity, and an increasingly challenging environment, preservation and particularly digitization of historical materials become vitally important in the context. There are many applicable African proverbs, including "No condition is permanent" and "Who knows tomorrow?" Many Nigerians and others have commented on what is referred to as "the lack of maintenance culture.” There are also climate extremes (and lack of climatecontrolled facilities), mold and dust, and insects, plus infrastructure issues like secure storage, fire-proofing, archival-quality folders, etc. One must keep in mind always that cultural heritage items are not permanent, personnel are not permanent, and the mission of an organization is not permanent.

\section{BACKGROUND}

BAPTIST MISSION OF NIGERIA (BMN). Baptist work in southern Nigeria began in 1850. Thomas Jefferson Bowen, a frontiersman who had fought in the Texas Revolution of the 1830s, was the first Baptist missionary to Nigeria, arriving at Badagry in the south in 1850 (following the Anglicans in 1842 and the Methodists in 1848). Christian mission work was largely confined (by British colonial policy) to the southern part of the country until after World War II. After this time, 
Baptist missionaries began visiting for short periods in the north around 1946. Baptist mission work in northeastern Nigeria began in the late 1950s, although some Baptist fellowships had earlier been established by Yoruba traders, civil servants, and laborers from the south. The institution where our project is housed, Baptist Theological Seminary, Kaduna (BTSK), began in 1948, was burned to the ground during a Muslim-Christian conflict (unrelated to Boko Haram) in 2000, and was rebuilt between 2001 and 2007. We also know the pain of loss, as the entire library and all historical records of the school were lost at that time.

BOKO HARAM (BH). Though the group has roots back into the 1970s, widespread violence and terrorism began in 2009 after the death in police custody of the group's founder, Yusuf Mohammed. Starting around 2011, BH conquered territory about the size of Belgium and began styling themselves as a caliphate. When the tide began to turn against them in early 2015, they returned to their previous guerrilla campaign and escalated the use of suicide bombers. They also perpetrate atrocities on a regular basis to subdue local populations and attract worldwide attention to their cause. The scale of the devastation is appalling: more than 20,000 people killed (more lethal than ISIS) and 2.5 million internally displaced persons.

"The human fallout of the crisis has been underreported, including the suffering of displaced people and the plight of women," Nnamdi Obasi, senior Nigeria analyst for the International Crisis Group, told The World Post earlier this year.

Life in NE Nigeria, he said, is "hellish.” (https://www.bbc.com/ news/world-africa-42735414)

Since 2009, at least 900 churches of all denominations have been destroyed by BH. (https://www.christianpost.com/news/900churches-in-nigeria-destroyed-by-boko-haram-173879/) Before BH, there were fourteen Baptist churches in Yobe State; however, all but one have had their buildings completely destroyed. Five are now worshipping again in the "rubble" of their buildings under temporary shelters. A small sample of destroyed Baptist churches in the northeastern states includes: Maiduguri, Baga, Ngala Gamboru (Borno State); Mubi (Adamawa State); Damaturu, Potiskum, Ngalda, and Buni Yadi (Yobe State). 
But brave Nigerian Christians are once again worshipping and working in the area.

One example is in the little railway town of Buni Yadi. Everyone has heard of the kidnapping of hundreds of schoolgirls in the town of Chibok (April 2014), but little outside attention has been given to tragedies in Buni Yadi both before and after the Chibok incident. In February 2014, 59 secondary-school boys were slaughtered by BH. The town was overrun and destroyed by BH in May 2014 (https://en.wikipedia. org/wiki/May_2014_Buni_Yadi_attack), and recaptured by the Nigerian military in March 2015 (https://www.naija.ng/398118-militaryreclaim-buni-yadi-buni-gari-from-boko-haram.html\#398118). Buni Yadi has continued to experience terrorist attacks and suicide bombers even earlier this year.

Despite this situation, Buni Yadi Baptist Church is now working to rebuild the fence around their devastated building, to avoid the property being used as a toilet by the next-door mosque (which was actually built on seized church land). While excavating to lay new foundations, human remains were discovered in shallow graves. Church officials learned that during the 2014-15 capture and occupation of Buni Yadi by BH, the group's leader, Abubakar Shekau, lived in pastorium, and executions done in front of the mosque were buried in the church property. The Nigerian Army had to be contracted to exhume the remains due to BH's policy of planting landmines in the graves to prevent family members from recovering the bodies of loved ones.

\section{REV. WILEY B. FAW}

Who was Wiley Faw? According to Rev. John Matthew, a Nigerian Baptist missionary (and former pastor of the Buni Yadi Baptist Church mentioned above), Rev. Faw "labored tirelessly ... he played the role of pastor, teacher, discipler" and funder of land purchases, even in the face of government hostility, throughout northeastern Nigeria. Wiley Faw and his wife Geneva served for thirty-two years as missionaries to Nigeria through the International Mission Board, Southern Baptist Convention. Arriving in the early 1960s, shortly after Nigeria's independence, Wiley worked first as a science teacher in a mission school in Jos, and later as a pioneer evangelist and church planter throughout the Northeast. Rev. and Mrs. Faw retired around 1995, and Rev. Faw died in 2016. (Mrs. Faw survives, though in very poor health physically 
and mentally.) According to missionary colleague Harriett Bowman, "Wiley Faw was a pioneer of the gospel in northern Nigeria. He had a huge impact which continues even today. People on earth may not recognize that one of the great ones has passed on, but heaven surely rejoices at the coming home of a great warrior."

The Faw files were recovered in 2015 (about twenty-five years after the Faws retired), in a storage container in the city of Gombe, on the edge of $\mathrm{BH}$ territory. The materials were housed somewhat haphazardly in two ancient filing cabinets in a loosely-sealed shipping container, with little regard for climate or pest control. The archive of Rev. Faw's working materials includes information from 110 churches in ten associations (local groupings) and four conferences (regional groupings). Most of these churches have no remaining documents or archival materials at all, and many of their buildings have been totally destroyed during the nine years of the insurgency. This has led to frequent opportunistic challenges to the churches' property rights.

\section{THE NORTHEASTERN NIGERIA BAPTIST DIGITAL HISTORY PROJECT}

The rationale for digital preservation is well-known:

ARTIFACTS Climatic extremes of heat, dryness, and humidity as well as insects may cause problems, especially in tropical climates. There may also be legal issues (as in laws with regard to possession of cultural-heritage items) in addition to changing administrative situations/priorities regarding space for display and storage.

DOCUMENTS Storage space may become an issue. Items may be packed up and moved without regard to organization or suitability of storage arrangements. Some primary historical documents may be labeled in a manner such that they are not recognized as valuable. We are aware of several examples in our context: at a sister seminary, an untrained person was made head of the library and "cleaned things up" by burning a large collection of old newspapers, some of which were the only extant copies of historical titles; a local mission organization made their move to new offices "easier" by abandoning many file cabinets of old mission records dating 
back a century, probably including original legal documents such as land titles acquired in the days when expatriate missionaries were in charge of most purchases.

When it comes to digitization, there are, of course, premium solutions for the "big dogs" (those with adequate funds): outsourcing, often with significant minimum charges, or high-speed scanners costing thousands of dollars. We have outsourced one large, fragile volume, but transporting to and from US was nerve-wracking. Unfortunately, even the most basic of high-speed book scanners is priced out of our range, and electricity issues are a critical factor (power surges, variable voltage, long periods with no power). In addition, lack of climate control is also very hard on sensitive equipment. Therefore, we had to look for affordable alternatives.

\section{DIGITAL PHOTOGRAPHY METHOD}

As the Baptist Mission of Nigeria started most of the Baptist work in Nigeria, we began this project several years ago by digitizing minutes of the Baptist Mission of Nigeria. These minutes, covering 1850-1991, are also used in researching Nigerian Baptist history, as many Baptist churches all over the country had significant missionary input in their founding, and the information describes activities of personnel that worked in Nigeria as missionaries.

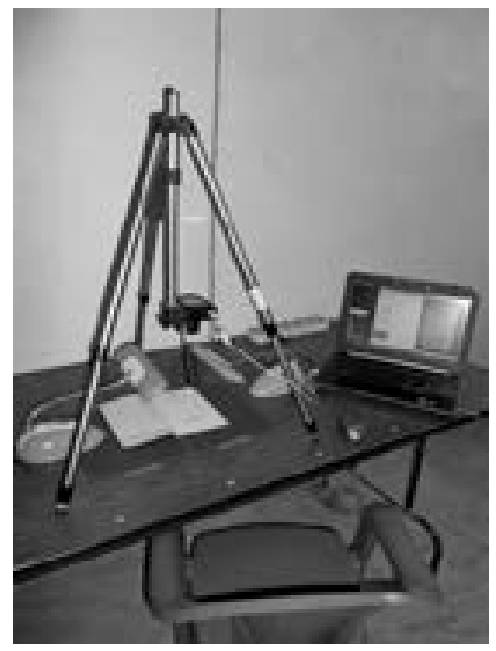

Photo credit: D'Anna Shotts

For these bound materials, we used a relatively inexpensive digital photography set-up (see photo at left), explained to us by Chris Beldan, an ATLA member now retired from the library of Lancaster Theological Seminary, Lancaster, PA, who used it in his work there. This involves a good-quality digital camera, a tripod capable of holding a camera facing down instead of out, a laptop with a remote-shutter program installed, and Adobe Acrobat software for creating PDFs from the resulting JPEG photos (and also for converting 
to OCR). This digitizing method is recommended by the Endangered Archives Project (EAP) of the British Library (https://eap.bl.uk/), and is explained and supported by articles and documents produced by the Hill Museum and Manuscript Library at St. John's University, Collegeville, Minnesota (www.vhmml.us/resource/downloads).

This method will be used again later for bound copies of minutes of other local organizations.

\section{SCANNER METHOD}

A few years later, files were recovered from the Faw archive described above, which contains vital information such as receipts of land purchase, legal documents, building plans, minutes and proceedings, and correspondence between Rev. Wiley Faw and church pastors and denominational leaders in the area where he served as a missionary. Since most of these materials are in single-sheet form, it made more sense to use some form of scanner.

For this phase of the project, we began with an HP300 flatbed scanner which was already on hand. This had the advantages of being (1) USB-powered, so not dependent on availability of electricity, and (2) cheap. Disadvantages were that it was relatively slow, requiring lots of manual adjustments and handling of files-and it was old and cantankerous.

We continued to search for a better solution, and eventually received a recommendation for the Fujitsu ScanSnap iX500 scanner, which sells for around $\$ 420$ and is compact enough to carry on-site when necessary. It feeds up to fifty pages at a time, automatically copies double-sided items, and can automatically do OCR conversion. (However, for our purposes, the double-sided function doesn't work for lined notebook papers and/or bleed-through from thin sheets written in ink.) There were other challenges particular to the material: widely varying sizes of sheets; much of the material is handwritten in Hausa language (and OCR doesn't work on handwriting or Hausa language!); and ink sketches and oversized, faint site plans. However, some items are marvelously evocative of place-like letters written on sheets torn from an oversized ledger from the Railway Corporation in a town where most Christians were working to build the railroad!

In addition to technical issues, we had to make the usual decisions facing an archival project: sorting files, eliminating duplicates, 
file labelling conventions and methodology, creating metadata, and OCR decisions.

\section{Physical and Administrative Challenges Encountered During the Project:}

- Fragile/poor quality of the papers used

- Many of the documents are handwritten in Hausa language; therefore, OCR not possible

- Power fluctuations/absence

- Lack of secure storage, archival folders, etc.

- No climate control

- Inadequate funding for better archival conditions, materials, and staffing

- Ownership/copyright (for the purpose of putting materials online)

- Materials in the files (some negative created by or regarding living persons)

\section{Future Challenges Anticipated:}

- Distance for potential users to access in person

- Lack of computer skills among potential users of digital resources

- Creating simple pathfinders/finding aids for the collection to enhance access

- Encouraging churches/institutions to contribute further material

\section{INTERVIEWS ABOUT THE PROJECT'S IMPACT}

For this presentation, interviews were carried out with several people who have used the materials in physical form. These interviews, intended to gauge the impact on users, are summarized briefly below:

REV. K. U. DANNAT, church historian, author, and lecturer at Baptist Theological Seminary, Kaduna, Nigeria, said the materials in the project would be of incalculable worth to him as a researcher and author as he prepares to write a book on the Baptist history of the Northeast. As a lecturer, he 
will encourage his students to use the archive to get a sense of what primary sources are like, their importance, and the difficulties surrounding their use as well.

REV. ABRAHAM DIMUES, Northeast Baptist Conference President and pastor of Bishara Baptist Church, Bauchi (one of the churches represented in the files). Rev. Dimues said their church is about to celebrate an anniversary, and wanted to write a history of the church. Unfortunately, due to several crises and violent incidents in their area in the last twenty years, there are no surviving documents from their founding period. In the archives, however, there is much material. Rev. Dimues said, “There are so many things [in the files] that we've been looking for, and we couldn't get them. But now ... the hardship is over. Ordination of the first deacons, a copy of the ordination service of the first pastor, many other things. This is wonderful."

REV. JOHN MATTHEW, Nigerian Baptist Convention missionary in Yobe State (and former pastor of Buni Yadi Baptist Church mentioned above) used materials from the files as the basis of his final-year research project on the influence of Yoruba Baptist traders on Baptist work in the Northeast: "Rev. Faw's impact was great ... He labored tirelessly in [what was then] Borno Baptist Association... To have access to his papers on this work has been of immense benefit to my research. I could not have completed my project without these materials.”

\section{FUTURE PROSPECTS}

So, what's next for the Northeastern Nigeria Baptist Digital History Project? We hope to:

- Discover more files as we make visits to churches in Northeastern Nigeria to encourage participation

- Digitize Northeastern Baptist Conference minutes (including Northern/Bethel Conference minutes covering the early history)

- Publicize the project to Baptist institutions and organizations

- Encourage the Nigerian Baptist Convention to set up an archival center in the Northern part of Nigeria 